\title{
Evidence of the impacts of metal mining and the effectiveness of mining mitigation measures on social-ecological systems in Arctic and boreal regions: a systematic map protocol
}

Neal R. Haddaway ${ }^{1,2^{*}}$ (D) Steven J. Cooke ${ }^{3}$, Pamela Lesser ${ }^{4}$, Biljana Macura' ${ }^{1}$ Annika E. Nilsson' ${ }^{1}$, Jessica J. Taylor ${ }^{3}$ and Kaisa Raito ${ }^{5}$

\begin{abstract}
Background: Mining activities, including prospecting, exploration, construction, operation, maintenance, expansion, abandonment, decommissioning and repurposing of a mine can impact social and environmental systems in a range of positive and negative, and direct and indirect ways. Mining can yield a range of benefits to societies, but it may also cause conflict, not least in relation to above-ground and sub-surface land use. Similarly, mining can alter environments, but remediation and mitigation can restore systems. Boreal and Arctic regions are sensitive to impacts from development, both on social and environmental systems. Native ecosystems and aboriginal human communities are typically affected by multiple stressors, including climate change and pollution, for example.

Methods: We will search a suite of bibliographic databases, online search engines and organisational websites for relevant research literature using a tested search strategy. We will also make a call for evidence to stakeholders that have been identified in the wider 3MK project (https://osf.io/cvh3u/). We will screen identified and retrieved articles at two distinct stages (title and abstract, and full text) according to a predetermined set of inclusion criteria, with consistency checks at each level to ensure criteria can be made operational. We will then extract detailed information relating to causal linkages between actions or impacts and measured outcomes, along with descriptive information about the articles and studies and enter data into an interactive systematic map database. We will visualise this database on an Evidence Atlas (an interactive, cartographic map) and identify knowledge gaps and clusters using Heat Maps (crosstabulations of important variables, such as mineral type and studied impacts). We will identify good research practices that may support researchers in selecting the best study designs where these are clear in the evidence base.
\end{abstract}

Keywords: Evidence synthesis, Extractive industries, Knowledges, Knowledge systems, Local knowledge, Resource extraction, Metal mines

\section{Background}

\section{On the impacts of mining}

Mining activities, including prospecting, exploration, construction, operation, maintenance, expansion, abandonment, decommissioning and repurposing of a mine can impact social and environmental systems in a range

*Correspondence: neal_haddaway@hotmail.com;

neal.haddaway@sei.org

1 Stockholm Environment Institute, Stockholm, Sweden

Full list of author information is available at the end of the article of positive and negative, and direct and indirect ways. Mine exploration, construction, operation, and maintenance may result in land-use change, and may have associated negative impacts on environments, including deforestation, erosion, contamination and alteration of soil profiles, contamination of local streams and wetlands, and an increase in noise level, dust and emissions (e.g. [1-5]). Mine abandonment, decommissioning and repurposing may also result in similar significant environmental impacts, such as soil and water contamination 
[6-8]. Beyond the mines themselves, infrastructure built to support mining activities, such as roads, ports, railway tracks, and power lines, can affect migratory routes of animals and increase habitat fragmentation $[9,10]$.

Mining can also have positive and negative impacts on humans and societies. Negative impacts include those on human health (e.g. [11]) and living standards [12], for example. Mining is also known to affect traditional practices of Indigenous peoples living in nearby communities [13], and conflicts in land use are also often present, as are other social impacts including those related to public health and human wellbeing (e.g. [14-17]. In terms of positive impacts, mining is often a source of local employment and may contribute to local and regional economies $[18,19]$. Remediation of the potential environmental impacts, for example through water treatment and ecological restoration, can have positive net effects on environmental systems [20]. Mine abandonment, decommissioning and repurposing can also have both positive and negative social impacts. Examples of negative impacts include loss of jobs and local identities [21], while positive impact can include opportunities for new economic activities [22], e.g. in the repurposing of mines to become tourist attractions.

\section{Mitigation measures}

'Mitigation measures' (as described in the impact assessment literature) are implemented to avoid, eliminate, reduce, control or compensate for negative impacts and ameliorate impacted systems [23]. Such measures must be considered and outlined in environmental and social impact assessments (EIAs and SIAs) that are conducted prior to major activities such as resource extraction [24, 25]. Mitigation of negative environmental impacts in one system (e.g. water or soil) can influence other systems such as wellbeing of local communities and biodiversity in a positive or negative manner [23]. A wide range of technological engineering solutions have been implemented to treat contaminated waters (e.g. constructed wetlands [26], reactive barriers treating groundwater [27], conventional wastewater treatment plants). Phytoremediation of contaminated land is also an area of active research [28].

Mitigation measures designed to alleviate the negative impacts of mining on social and environmental systems may not always be effective, particularly in the long-term and across systems, e.g. a mitigation designed to affect an environmental change may have knock on changes in a social system. Indeed, the measures may have unintentional adverse impacts on environments and societies. To date, little research appears to have been conducted into mitigation measure effectiveness, and we were unable to find any synthesis or overview of the systems-level effectiveness of metal mining mitigation measures.

\section{Mining in the Arctic}

Boreal and Arctic regions are sensitive to impacts from mining and mining-related activities [29, 30], both on social and environmental systems: these northern latitudes are often considered harsh and thus challenging for human activities and industrial development. However, the Arctic is home to substantial mineral resources [31, 32] and has been in focus for mining activities for several 100 years, with a marked increase in the early 20th century and intensifying interest in exploration and exploitation in recent years to meet a growing global demand for metals (Fig. 1). Given the region's geological features and society's need for metals, resource extraction is likely to dominate discourse on development of northern latitudes in the near future. As of 2015, there were some 373 mineral mines across Alaska, Canada, Greenland, Iceland, The Faroes, Norway (including Svalbard), Sweden, Finland and Russia (see Table 1), with the top five minerals being gold, iron, copper, nickel and zinc [33].

Many topics relating to mining and its impacts on environmental and social systems are underrepresented in the literature as illustrated by the following example. The Sami people are a group of traditional people inhabiting a region spanning northern Norway, Sweden, Finland and Russia. Sami people are affected by a range of external pressures, one of which pertains to resource extraction and land rights, particularly in relation to nomadic reindeer herding. However, there is almost no published research on the topic [34].

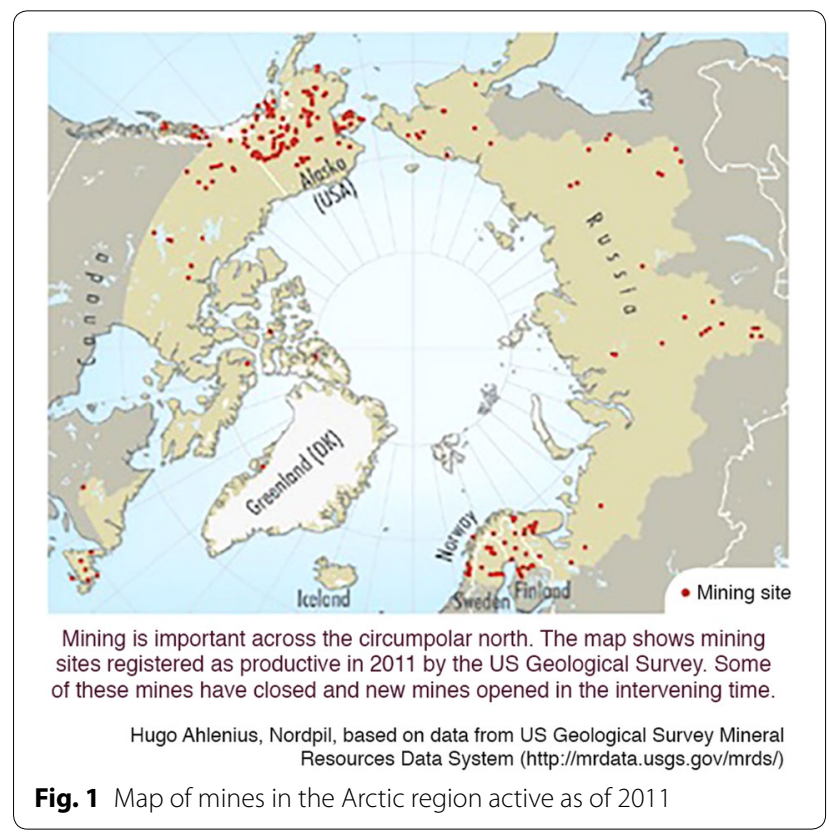


Table 1 List of minerals mined across Arctic and boreal countries (Alaska (US), Canada, Greenland, Iceland, The Faroes, Norway (including Svalbard), Sweden, Finland and Russia) and the number of mines according to a 2015 survey [33]

\begin{tabular}{lc}
\hline Main metal mined & $\begin{array}{c}\text { Number } \\
\text { of mines }\end{array}$ \\
\hline Gold & 144 \\
Iron & 58 \\
Copper & 45 \\
Nickel & 39 \\
Zinc & 27 \\
Diamonds & 15 \\
Uranium & 8 \\
Potash & 7 \\
Silver & 6 \\
Molybdenum & 4 \\
Lead & 4 \\
Chromium & 3 \\
Titanium & 2 \\
Tin & 2 \\
Tungsten & 1 \\
Palladium & 1 \\
Nobelium & 1 \\
Platinum & 1 \\
Lithium & 1 \\
Rare earth oxides & 1 \\
Antimony & 1 \\
Manganese & 1 \\
Aluminium & 1 \\
\hline & 1 \\
\hline
\end{tabular}

The literature on the environmental and social impacts of mining has grown in recent years, but despite its clear importance, there has been little synthesis of research knowledge pertaining to the social and environmental impacts of metal mining in Arctic and boreal regions. The absence of a consolidated knowledge base on the impacts of mining and the effectiveness of mitigation measures in Arctic and boreal regions is a significant knowledge gap in the face of the continued promotion of extractive industries. There is thus an urgent need for approaches that can transparently and legitimately gather research evidence on the potential environmental and social impacts of mining and the impacts of associated mitigation measures in a rigorous manner.

\section{Stakeholder engagement}

This systematic map forms a key task within a broader knowledge synthesis project called 3MK (Mapping the impacts of Mining using Multiple Knowledges, https ://osf.io/cvh3u/). The stakeholder group for this map includes representatives of organisations affected by the

broader 3MK project knowledge mapping project or who have special interests in the project outcome. We define stakeholders here as all individuals or organisations that might be affected by the systematic map work or its findings $[35,36]$, and thus broadly includes researchers and the Working and Advisory Group for this project.

Invitations to be included in this group were based on an initial stakeholder mapping process and soliciting expressions of interest (see Stakeholder Engagement Methodology Document, https://osf.io/cvh3u/). This group included government ministries and agencies such as the Ministry of Enterprise and Innovation, the Mineral Inspectorate (Bergstaten) and County Administrative Boards, the mining industries' branch organisation (Svemin) and individual companies such as LKAB Minerals and Boliden $A B$, Sami organisations, including the Sami Parliament, related research projects, and representatives of international assessment processes, such as activities within the Arctic Council. Stakeholders were invited to a specific meeting (held at Stockholm Environment Institute in September 2018) to help refine the scope, define the key elements of the review question, finalise a search strategy, and suggest sources of evidence, and also to subsequently provide comments on the structure of the protocol .

\section{Objective of the review}

The broader $3 \mathrm{MK}$ project aims to develop a multiple evidence base methodology [37] combining systematic review approaches with documentation of Indigenous and local knowledge and to apply this approach in a study of the impacts of metal mining and impacts of mitigation measures. This systematic map aims to answer the question:

What research evidence exists on the impacts of metal mining and its mitigation measures on social and environmental systems in Arctic and boreal regions?

The review question has the following key elements:

Population:

Intervention/exposure:

Impacts (direct and indirect, positive and negative) associated with metal mining (for gold, iron, copper, nickel, zinc, 


\section{Comparator:}

\section{Outcome:}

Data type: silver, molybdenum and lead) or its mitigation measures. We focus on these metals as they represent approximately $88 \%$ of Arctic and boreal mines (according to relevant country operating mine data from 2015, [33]), and contains the top 5 minerals extracted in the region (gold, iron, copper, nickel and zinc). Furthermore, these minerals include all metals mined within Sweden, the scope of a related workstream within the broader $3 \mathrm{MK}$ project (https://osf.io/cvh3u/).

For quantitative research; the absence of metal mining or metal mining mitigation measures-either prior to an activity or in an independent, controlled location lacking such impacts. Additionally, alternative mining systems is a suitable comparator. For qualitative research; comparators are typically implicit, if present and will thus not be required.

Any and all outcomes observed in social and environmental systems described in the literature will be iteratively identified and catalogued.

Both quantitative and qualitative research will be included.

\section{Methods}

The review will follow the Collaboration for Environmental Evidence Guidelines and Standards for Evidence Synthesis in Environmental Management [38] and it conforms to ROSES reporting standards [39] (see Additional file 1).

\section{Searching for articles \\ Bibliographic database searches}

We will search bibliographic databases using a tested search string adapted to each database according to the necessary input syntax of each resource. The Boolean version of the search string that will be used in Web of

Science Core Collections can be found in Additional file 2.

We will search across 17 bibliographic databases as show in Table 2. Bibliographic database searches will be performed in English only, since these databases catalogue research using English titles and abstracts.

\section{Web-based search engines}

Searches for academic (i.e. file-drawer) and organisational grey literature (as defined by [40]) will be performed in Google Scholar, which has been shown to be effective in retrieving these types of grey literature [41]. The search strings used to search for literature in Google Scholar are described in detail in Additional file 3.

Search results will be exported from Google Scholar using Publish or Perish [42], which allows the first 1000 results to be exported. These records will be added to the bibliographic database search results prior to duplicate removal.

\section{Organisational websites}

In order to identify organisational grey literature, we will search for relevant evidence across the suite of organisational websites listed in Table 3. For each website, we will save the first 100 search results from each search string as PDF/HTML files and screening the results in situ, recording all relevant full texts for inclusion in the systematic map database. The search terms used will be based on the same terms used in the Google Scholar searches described above but will be adapted iteratively for each website depending on the relevance of the results obtained. In addition, we will hand search each website to locate and screen any articles found in publications or bibliography sections of the sites. All search activities will be recorded and described in the systematic map report.

\section{Bibliographic searches}

Relevant reviews that are identified during screening will be reserved for assessment of potentially missed records. Once screening is complete (see below), we will screen the reference lists of these reviews and include relevant full texts in the systematic map database. We will also retain these relevant reviews in an additional systematic map database of review articles.

\section{Estimating the comprehensiveness of the search}

A set of 41 studies known to be relevant have been provided by the Advisory Team and Working Group (review team); the benchmark list (see Additional file 4). During scoping and development of the search string, the bibliographic database search results will be checked to ascertain whether any of these studies were not found. For any cases where articles on the benchmark list are missed by 
Table 2 List of bibliographic databases to be searched for evidence along with the platform and subscription through which they will be accessed

\begin{tabular}{lll}
\hline Database & Portal & Comments \\
\hline 1. Academic Search Premier & EBSCO Host & Stockholm University subscription \\
2. Agricola & National Agricultural Library & Open Access \\
3. AGRIS & Food and Agriculture Organisation & Open Access \\
4. Aquatic Sciences and Fisheries Abstracts & ProQuest & Stockholm University subscription \\
5. CAB Abstract & CAB Direct & Stockholm University subscription \\
6. DART-Europe E-theses Portal & DART-Europe E-theses Portal & Open Access \\
7. DOAJ & DOAJ & Open Access \\
8. EconLit & EbscoHost & Stockholm University subscription \\
9. EThOS & British Library & Open Access \\
10. GreenFILE & EbscoHost & Stockholm University subscription \\
11. International Bibliography of the Social Sciences (IBSS), Sociologi- & Social Science Premium Collection (via & Stockholm University subscription \\
cal Abstracts, and Worldwide Political Science Abstracts & ProQuest) & Stockholm University subscription \\
12. JSTOR & JSTOR & Stockholm University subscription \\
13. MEDLINE & Web of Science & Stockholm University subscription \\
14. ProQuest Dissertations and Theses & ProQuest & Stockholm University subscription \\
15. Russian Science Citation Index & Web of Science & Stockholm University subscription \\
16. Scopus & Scopus & Stockholm University subscription \\
17. Web of Science Core Collections & Web of Science &
\end{tabular}

the draft search string, we will examine why these studies may have been missed and adapt the search string accordingly.

\section{Search update}

We will perform a search update immediately prior to completion of the systematic map database (i.e. once coding and meta-data is completed). The search strategy for bibliographic databases will be repeated using the same search string, restricting searches to the time period after the original searches were performed. New search results will be processed in the same way as original search results.

\section{Assembling a library of search results}

Following searching, we will combine results in a review management platform (e.g. EPPI-Reviewer) and duplicates will be removed using a combination of automated removal and manual screening.

\section{Article screening and study eligibility criteria Screening process}

We will screen records at three levels: title, abstract and full text. Screening will be performed using a review management platform (e.g. Rayyan, EPPI Reviewer, Colandr).

\section{Consistency checking}

A subset of $10 \%$ of all titles and abstracts will be screened by two reviewers, with all disagreements discussed in detail. Refinements of the inclusion criteria will be made in liaison with the entire review team where necessary. A kappa test will be performed on the outputs of screening of this subset and where agreement is below $\mathrm{k}=0.6$, a further $10 \%$ of records will be screened and tested. Only when a kappa score of greater than 0.6 is obtained will a single reviewer screen the remaining records. Consistency checking on a subset of $10 \%$ will be undertaken at full text screening in a similar manner, followed by discussion of all disagreements. A kappa test will be performed and consistency checking repeated on a second subset of $10 \%$ where agreements is below $\mathrm{k}=0.6$. Consistency checking will be repeated until a score of greater than 0.6 is obtained.

\section{Eligibility criteria}

The following inclusion criteria will be used to assess relevance of studies identified through searching. All inclusion criteria will be used at full text screening, but we believe that data type and comparator are unlikely to be useful at title and abstract screening, since this information is often not well-reported in titles or abstracts.

Eligible population: We will include social, technological and 
Table 3 List of organisational websites that will be searched for organisational grey literature

\section{Organisation}

1. Swedish Environmental Protection Agency (SEPA)

2. Finnish Environment Institute

3. United States Environmental Protection Agency

4. European Commission

5. Resource Extraction and Sustainable Arctic Communities project (REXSAC)

6. Health Canada

7. European Environment Agency

8. Alaska Department of Natural Resources

9. Arctic Centre (University of Lapland)

10. Arctic Council

11. Bioforsk

12. Bureau of Land Management, US Dept. of the Interior

13. Conservation of Arctic Flora and Fauna (CAFF)

14. Environment and Climate Change Canada

15. Finnish Game and Fisheries Research Institute

16. Greenland Institute of Natural Resources

17. GRID Arendal

18. International Union for Conservation of Nature

19. Ministry of Natural Resources of the Russian Federation

20. Natural Resources Canada

21. Nordic Council of Ministers

22. Northern Research Institute (NORUT)

23. Norwegian Directorate for Nature Management

24. Norwegian Institute for Nature Research (NINA)

25. Norwegian Polar Institute

26. Russian Guild of Ecologists

27. Russian Regional Environmental Centre

28. Sámediggi (Finnish Sami Parliament)

29. Sámediggi (Norwegian Sami Parliament)

30. Sápmi (Sami Parliament in Sweden)

31. Swedish University of Agricultural Sciences (SLU)

32. United Nations Environment Programme

33. United States Environmental Protection Agency

34. United States Fish and Wildlife Service

35. University of Alaska Anchorage

36. Arctic Monitoring and Assessment Programme (AMAP)

37. Norwegian Environment Agency

38. Canadian Northern Contaminants Program

39. Norwegian Institute for Water Research (NIVA)

40. Swedish Agency for Marine and Water Management

41. United Nations Environment Programme

42. United States Environmental Protection Agency

43. Business and Biodiversity Offset Program (BBOP)

44. International Zinc Association

45. International Lead Association

46. International Lead and Zinc Study Group

47. Copper Alliance - The International Copper Association

48. International Copper Study Group

49. International Iron Metallics Association
URL

http://www.swedishepa.se/

http://www.environment.fi/

http://www3.epa.gov/

http://ec.europa.eu/

https://www.rexsac.org/

http://www.hc-sc.gc.ca

http://www.eea.europa.eu/

http://dnr.alaska.gov

http://www.arcticcentre.org

http://www.arctic-council.org

http://www.bioforsk.no

http://www.blm.gov

http://www.caff.is

http://www.ec.gc.ca

http://www.rktl.fi

http://www.natur.gl

http://www.grida.no

http://www.iucn.org

http://www.mnr.gov.ru

http://www.nrcan.gc.ca

http://www.norden.org

http://www.norut.no

http://www.dirnat.no

http://www.nina.no

http://www.npolar.no

http://www.ecoguild.ru

http://www.rusrec.ru

http://www.samediggifi

http://www.sametinget.no

http://www.eng.samer.se

http://www.slu.se

http://www.unep.org

http://www.epa.gov

http://www.fws.gov

http://www.uaa.alaska.edu

https://www.amap.no/

http://www.miljodirektoratet.no/en/

http://www.science.gc.ca/eic/site/063.nsf/eng/h_7A463DBA.html

http://www.niva.no

http://www.havochvatten.se

http://www.unep.org

http://www.epa.gov

http://bbop.forest-trends.org/

https://www.zinc.org/about/

https://www.lla-lead.org/home

http://www.ilzsg.org/static/home.aspx

http://copperalliance.org/

https://www.icsg.org/

https://www.metallics.org/ 
Table 3 (continued)

Organisation
50. World Steel Association
51. Nickel Institute
52. International Nickel Study Group
53. Applied Environmental Research Center, University of Alaska Anchor-
age

54. Polar Environmental Atmospheric Research Laboratory (PEARL)

55. Aurora Research Institute

56. Arctic Health

57. Centre for Aboriginal Health Research

58. Canadian Institute of Health Research (CIHR)

59. ArcticNet

60. Centre for Indigenous Peoples' Nutrition and Environment (CINE)

61. Centre for Inuit Health and Changing Environments

62. Nunavut Research Institute

63. Polar Knowledge Canada (POLAR)

64. Yukon Research Centre

65. Arctic Health (Finland)

66. Thule Institute

67. Arctic Research Centre

68. Greenland Institute for Circumpolar Health Research

69. Isaaffik

70. University of Iceland Centre of Public Health Sciences

71. Centre for Saami Health Research

72. Institute for Circumpolar Health Studies, University of Alaska

73. Institute of Arctic Biology

74. Arctic Studies Center

75. International Arctic Research Center (IARC)

76. International Arctic Social Sciences Association (IASSA)

77. Polar Research Board

78. The Arctic Institute: Center for Circumpolar Security Studies

79. Greenland Institute of Natural Resources

80. Fridtjof Nansen Institute

81. Stockholm Environment Institute

82. RAND Corporation

83. Strategic innovation programme for the Swedish mining and metal producing industry

84. International Resource Panel

85. Swedish Geological Survey

86. Geological Survey of Finland

87. Geological survey of Norway

88. Geological Survey of Denmark and Greenland (GEUS)

89. Faroese Geological Survey: Jarðfeingi

90. Geological Survey of Canada-Natural Resources Canada

91. Alaska Division of Geological and Geophysical Surveys

92. All-Russian Geological Research Institute. A.P. Karpinsky

93. The World Bank
URL

https://www.worldsteel.org/

https://www.nickelinstitute.org/

http://www.insg.org/

https://www.uaa.alaska.edu/academics/business-enterprise-institute/appli ed-environmental-research-center/index.cshtml

https://eu-interact.org/field-sites/polar-environment-atmospheric-resea rch-laboratory-pearl/

http://nwtresearch.com/research-projects/information-technology/arcti c-collaborative-environment

https://arctichealth.nIm.nih.gov/publications_and_research/242/resea rch/244/organizations

http://umanitoba.ca/centres/cahr/

http://www.cihr-irsc.gc.ca/e/193.html

http://www.arcticnet.ulaval.ca/

http://www.mcgill.ca/cine/

http://www.nasivvik.ca/

http://www.nri.nu.ca/

http://www.canada.ca/en/polar-knowledge/index.html

http://www.yukoncollege.yk.ca/research

http://www.oulu.fi/arctichealth/

http://www.oulu.fi/thuleinstitute/

http://arctic.au.dk/

http://www.pi.gl/da

http://www.isaaffik.org/

http://english.hi.is/public_health_sciences/public_health_sciences

http://en.uit.no/ansatte/organisasjon/hjem?p_menu=42374\&p_dimen sion_id=88182

http://www.uaa.alaska.edu/instituteforcircumpolarhealthstudies/

http://www.iab.uaf.edu/

http://www.mnh.si.edu/arctic/index.html

http://www.iarc.uaf.edu/

http://www.iassa.org/

http://dels.nas.edu/prb

http://www.thearcticinstitute.org/

https://education.uarctic.org/universities/greenland/23857/greenland-insti tute-of-natural-resources

https://www.fni.no/

http://www.sei.org/

https://www.rand.org/topics/russia.html

https://www.sipstrim.se/

http://www.resourcepanel.org/

https://www.sgu.se/en/

http://en.gtk.fi/

https://www.ngu.no/en

http://www.eng.geus.dk/

http://jffo/en/

https://www.nrcan.gc.ca/earth-sciences/science/geology/gsc/17100

http://dggs.alaska.gov/

http://www.vsegei.ru/

https://www.worldbank.org/ 
Table 3 (continued)

\begin{tabular}{|c|c|}
\hline Organisation & URL \\
\hline 94. Uppsala University Department of Earth Sciences & $\begin{array}{l}\text { https://www.geo.uu.se/research/geophysics/ongoing-research/miner } \\
\text { al-exploration/ }\end{array}$ \\
\hline 95. World Gold Council & https://www.gold.org/ \\
\hline 96. International Molybdenum Association (IMOA) & https://www.imoa.info/index.php \\
\hline 97. University of Eastern Finland & http://www.uef.fi/en/etusivu \\
\hline 98. Luleå University of Technology & https://www.ltu.se/?|=en \\
\hline \multicolumn{2}{|l|}{ 99. Saami Council } \\
\hline 100. The European Network for Sustainable Quarrying and Mining & https://ensqm.weebly.com/ \\
\hline 101. Finnish Network for Sustainable Mining & $\begin{array}{l}\text { https://www.min-guide.eu/mineral-policy/network-sustainable-minin } \\
\text { g-1814 }\end{array}$ \\
\hline 102. NGO Mining Working Group & https://miningwg.com/ \\
\hline 103. Cultural Survival & https://www.culturalsurvival.org/ \\
\hline 104. Federal Agency for Mineral Resources & http://government.ru/en/department/53/ \\
\hline 105. International Council on Mining and Minerals & https://www.icmm.com/ \\
\hline
\end{tabular}

environmental systems in Arctic and boreal regions based on political boundaries as follows (this encompasses various definitions of boreal zones, rather than any one specific definition for comprehensiveness and ease of understanding): Canada, USA (Alaska), Greenland, Iceland, the Faroe Islands, Norway (including Svalbard), Sweden, Finland, and Russia.

Eligible intervention/exposure: We will include all impacts (positive, negative, direct and indirect) associated with any aspect of metal mining and its mitigation measures. We will include research pertaining to all stages of mining, from prospecting onwards as follows: prospecting, exploration, construction, operation, maintenance, expansion, abandonment, d e co m m is sion ing, reopening and repurposing. Eligible mines will include those of gold, iron, copper, nickel, zinc, silver, molybdenum and lead.

Eligible comparator: For quantitative research; the absence of metal mining or metal mining mitigation measures-either prior to an activity or in an independent, controlled location lacking such impacts. For qualitative research; comparators are typically implicit, if present and will thus not be required.

Eligible outcome:

Any and all outcomes (i.e. measured impacts) observed in social, technological and environmental systems will be included.

Eligible data type: We will include both quantitative and qualitative research.

Eligible study type: $\quad$ We will include both primary empirical research and secondary research (reviews will be catalogued in a separate database). Modelling studies and commentaries will not be included. 
For all articles excluded at title and abstract or full text levels, reasons for exclusion will be provided in the form of one or more a priori exclusion criteria as follows:

- Exclude, not Arctic or boreal (population).

- Exclude, no primary data (i.e. commentary, modelling article or similar) (study type).

- Exclude, no comparator [for quantitative studies only].

- Exclude, not mining or mining mitigation measures (intervention/exposure).

- Exclude, not relevant metal mining (intervention/ exposure) [this category is related to the above intervention/exposure exclusion criteria but will only be selected where all other criteria are met, facilitating expansion of the map in the future].

- Exclude, not an existing mine (planned or unrealised mining activity).

\section{Full text retrieval}

We will attempt to retrieve full texts of relevant abstracts using Stockholm University and Carleton University library subscriptions. Where full texts cannot be readily retrieved this way (or via associated library inter-loan networks), we will make use of institutional access provided to our Advisory Team members, including: University College London, KTH, University of Lapland, and SLU. Where records still cannot be obtained, requests for articles will be sent to corresponding authors where email addresses are provided and/or requests for full texts will be made through ResearchGate.

\section{Study validity assessment}

This systematic map will not involve an assessment of study validity (an optional part of systematic maps), although some extracted meta-data and coding will relate to internal validity.

\section{Demonstrating procedural objectivity}

None of the review team has authored or worked on research within this field prior to starting this project, but members of the Advisory Team and project Working Group will be prevented from providing advice or comments relating specifically to research papers to which they may have contributed.

Table 4 Variables that will be extracted as meta-data (descriptive information) and codes during systematic mapping

\begin{tabular}{|c|c|c|}
\hline Variable & Description & Meta-data or coding \\
\hline Study country/region & $\begin{array}{l}\text { Country/region in which study was undertaken (region applicable for Canadian } \\
\text { province or Russian Districts) }\end{array}$ & Coding \\
\hline Study location & Short textual description of study location & Meta-data \\
\hline Latitude & $\begin{array}{l}\text { Study location latitude as quoted in the report (or obtained from nearest named } \\
\text { location) }\end{array}$ & Meta-data \\
\hline Longitude & $\begin{array}{l}\text { Study location longitude as quoted in the report (or obtained from nearest named } \\
\text { location) }\end{array}$ & Meta-data \\
\hline Köppen-Geiger climate zone & Study location climate zone according to Kottek et al. [43] & Coding \\
\hline Mine type & Surface mining, underground mining, highwall mining & Coding \\
\hline Mine description & $\begin{array}{l}\text { Short textual description (possibly a quotation, identified as such) of the type of } \\
\text { mine investigated }\end{array}$ & Meta-data \\
\hline Status of mine & $\begin{array}{l}\text { Prospecting, exploration, construction, operation, maintenance, expansion, aban- } \\
\text { donment, decommissioning, reopening, repurposing }\end{array}$ & Coding \\
\hline Status of mine description & $\begin{array}{l}\text { Short textual description (possibly a quotation, identified as such) of the status of } \\
\text { the mine }\end{array}$ & Meta-data \\
\hline Metal & Gold, iron, copper, nickel, zinc, silver, molybdenum and lead & Coding \\
\hline Intervention/exposure & Mining impacts/mitigation impacts & Coding \\
\hline Intervention/exposure description & $\begin{array}{l}\text { Short textual description (possibly a quotation, identified as such) of the mining or } \\
\text { mitigation impact investigated }\end{array}$ & Meta-data \\
\hline Timeframe of mining/mitigation impacts & Time since investigated activity began at time study was completed & Meta-data \\
\hline Outcome & $\begin{array}{l}\text { Social or ecological outcomes measured during the study, iterative cataloguing into } \\
\text { distinct categories }\end{array}$ & Meta-data \\
\hline Outcome description & $\begin{array}{l}\text { Short textual description (possibly a quotation, identified as such) of the outcome } \\
\text { measured }\end{array}$ & Meta-data \\
\hline Outcome measurement method & $\begin{array}{l}\text { Short textual description (possibly a quotation, identified as such) of the method of } \\
\text { outcome measurement }\end{array}$ & Meta-data \\
\hline
\end{tabular}




\section{Data coding strategy}

We will extract and code a range of variables, outlined in Table 4. All meta-data and coding will be included in a detailed systematic map database, with each line representing one study-location (i.e. each independent study conducted in each independent location).

Meta-data extraction and coding will be performed by multiple reviewers following consistency checking on an initial coding of subset of between 10 and 15 full texts, discussing all disagreements. The remaining full texts will then be coded. If resources allow we may contact authors by email with requests for missing information.

\section{Study mapping and presentation}

We will display the results of the systematic mapping using a ROSES flow diagram [44]. We will narratively synthesise the relevant evidence base in our systematic map using descriptive plots and tables showing the number of studies identified across the variables described above. For more complex data, we will use heat maps to display the volume of evidence across multiple variables (see "Knowledge gap and cluster identification strategy", below).

We will display the contents of our systematic map database in an Evidence Atlas; an interactive, web-based geographical information system showing all meta-data and coding on a cartographic map.

\section{Knowledge gap and cluster identification strategy}

We will use interactive heat maps (pivot charts) to display the volume of evidence across multiple dimensions of meta-data in order to identify knowledge gaps (subtopics un- or under-represented by evidence) and knowledge clusters (sub-topics with sufficient evidence to allow full synthesis). Examples of meta-data variables that will be used together include (this is an indicative rather than exhaustive list):

- Study location (country or broad region) versus outcome.

- Study location (country or broad region) versus mine type.

- Study location (country or broad region) versus data/ study type.

- Outcome versus mine type.

- Outcome versus data/study type.

\section{Additional files}

Additional file 1. ROSES form for systematic map protocols.

Additional file 2. Boolean format search string for database searches.

Additional file 3. Google Scholar search strategy.

Additional file 4. Benchmark list of relevant articles for comprehensiveness checking of search strategy.

\section{Authors' contributions}

$\mathrm{NRH}$ drafted the manuscript. All authors read and approved the final manuscript.

\section{Author details \\ 1 Stockholm Environment Institute, Stockholm, Sweden. ${ }^{2}$ Africa Centre for Evi- dence, University of Johannesburg, Johannesburg, South Africa. ${ }^{3}$ Canadian Centre for Evidence-Based Conservation and Environmental Management, Ottawa, Canada. ${ }^{4}$ Faculty of Social Sciences, University of Lapland, Rovaniemi, Finland. ${ }^{5}$ Division of Environmental Communication, Department of Urban and Rural Development, Swedish University of Agricultural Sciences, Uppsala, Sweden.}

\section{Acknowledgements}

We thank the project Advisory Team for comments on the project and the draft: the team consisted of Dag Avango, Steven Cooke, Sif Johansson, Rebecca Lawrence, Pamela Lesser, Björn Öhlander, Kaisa Raito, Rebecca Rees, and Maria Tengö. We also thank the $3 \mathrm{MK}$ stakeholder group for valuable input. We also thank Mistra EviEM for co-funding the first Advisory Group meeting and publication fees for the systematic map.

\section{Competing interests}

The authors declare they have no competing interests.

\section{Availability of data and materials}

Not applicable.

\section{Consent for publication \\ Not applicable.}

Ethics approval and consent to participate

Not applicable.

\section{Funding}

This manuscript is part of a project (3MK: Mapping the impacts of Mining using Multiple Knowledges) funded by a Formas Open Call Grant (2017-00683).

\section{Publisher's Note}

Springer Nature remains neutral with regard to jurisdictional claims in published maps and institutional affiliations.

Received: 13 November 2018 Accepted: 6 February 2019

Published online: 21 February 2019

\section{References}

1. Appleton J, Weeks J, Calvez J, Beinhoff C. Impacts of mercury contaminated mining waste on soil quality, crops, bivalves, and fish in the Naboc River area, Mindanao, Philippines. Sci Total Environ. 2006;354:198-211.

2. Dudka S, Adriano DC. Environmental impacts of metal ore mining and processing: a review. J Environ Qual. 1997;26:590-602.

3. Sonter LJ, Moran CJ, Barrett DJ, Soares-Filho BS. Processes of land use change in mining regions. J Clean Prod. 2014;84:494-501.

4. Swenson JJ, Carter CE, Domec J-C, Delgado Cl. Gold mining in the Peruvian Amazon: global prices, deforestation, and mercury imports. PLoS ONE. 2011;6:e18875. 
5. Warhate S, Yenkie M, Chaudhari M, Pokale W. Impacts of mining activities on water and soil. J Environ Sci Eng. 2006;48:81-90.

6. Mchaina D. Environmental planning considerations for the decommissioning, closure and reclamation of a mine site. Int J Surf Min Reclam Environ. 2001;15:163-76.

7. Navarro M, Pérez-Sirvent C, Martínez-Sánchez M, Vidal J, Tovar P, Bech J. Abandoned mine sites as a source of contamination by heavy metals: a case study in a semi-arid zone. J Geochem Explor. 2008;96:183-93.

8. Veiga MM, Hinton JJ. Abandoned artisanal gold mines in the Brazilian Amazon: a legacy of mercury pollution. In: Natural resources forum. Wiley Online Library. 2002. p. 15-26.

9. Anttonen M, Kumpula J, Colpaert A. Range selection by semi-domesticated reindeer (Rangifer tarandus tarandus) in relation to infrastructure and human activity in the boreal forest environment, northern Finland. Arctic. 2011:1-14.

10. Johnson CJ, Boyce MS, Case RL, Cluff HD, Gau RJ, Gunn A, Mulders R. Cumulative effects of human developments on arctic wild life. Wildl Monogr. 2005;160:1-36.

11. Stephens $C$, Ahern M. Worker and community health impacts related to mining internationally: a rapid review of the literature. 2001

12. Loayza N, Rigolini J. The local impact of mining on poverty and inequality: evidence from the commodity boom in Peru World Dev 2016:84.219-34.

13. Gibson G, Klinck J. Canada's resilient north: the impact of mining on aboriginal communities. Pimatisiwin. 2005;3:116-39.

14. Hilson G. An overview of land use conflicts in mining communities. Land Use Policy. 2002;19:65-73.

15. Hossain D, Gorman D, Chapelle B, Mann W, Saal R, Penton G. Impact of the mining industry on the mental health of landholders and rural communities in southwest Queensland. Aust Psychiatry. 2013;21:32-7.

16. Nakazawa K, Nagafuchi O, Kawakami T, Inoue T, Yokota K, Serikawa Y, Cyio B, Elvince R. Human health risk assessment of mercury vapor around artisanal small-scale gold mining area, Palu city, Central Sulawesi, Indonesia. Ecotoxicol Environ Saf. 2016;124:155-62.

17. Zhang $X$, Yang L, Li Y, Li H, Wang W, Ye B. Impacts of lead/zinc mining and smelting on the environment and human health in China. Environ Monit Assess. 2012;184:2261-73.

18. Fleming DA, Measham TG. Local job multipliers of mining. Resour Policy. 2014:41:9-15.

19. Knobblock EA, Pettersson Ö. Restructuring and risk-reduction in mining: employment implications for northern Sweden. Fenn Int J Geogr. 2010;188:61-75

20. Jain R, Cui Z, Domen J. Environmental impacts of mining. In: Jain R, Cui Z, Domen J, editors. Environmental impact of mining and mineral processing: management, monitoring, and auditing strategies. Amsterdam: Elsevier; 2016. p. 53-157.

21. Keeling A, Sandlos J. Ghost towns and zombie mines: the historical dimensions of mine abandonment, reclamation, and redevelopment in the Canadian North. In: Bocking S, Martin B, editors. Ice Blink: Navigating Northern Environmental History; 2011. p. 377-420.

22. Mitchell CJ, O'Neill K. The Sherriff Creek Wild life Sanctuary: further evidence of mine-site repurposing and economic transition in northern Ontario. Extr Ind Soc. 2017:4:24-35.

23. Jain R, Cui Z, Domen J. Environmental impact of mining and mineral processing: management, monitoring, and auditing strategies. Oxford: Butterworth-Heinemann; 2016.

24. The Sustainable Development Working Group (SDWG) of the Arctic Council. Circumpolar Information Guide on Mining for Indigenous Peoples and Northern Communities. 2011.
25. Worldwide Environmental Law Alliance. Guidebook for evaluating mining project EIAs. Eugene: Environmental Law Alliance Worldwide; 2010.

26. Gandy CJ, Davis JE, Orme PHA, Potter HAB, Jarvis AP. Metal removal mechanisms in a short hydraulic residence time subsurface flow compost wetland for mine drainage treatment. Ecol Eng. 2016;97:179-85.

27. Obiri-Nyarko F, Grajales-Mesa SJ, Malina G. An overview of permeable reactive barriers for in situ sustainable groundwater remediation. Chemosphere. 2014;111:243-59.

28. Mahar A, Wang P, Ali A, Awasthi MK, Lahori AH, Wang Q, Li RH, Zhang ZQ. Challenges and opportunities in the phytoremediation of heavy metals contaminated soils: a review. Ecotoxicol Environ Saf. 2016;126:111-21.

29. Bennett JR, Shaw JD, Terauds A, Smol JP, Aerts R, Bergstrom DM, Blais JM, Cheung WW, Chown SL, Lea M-A. Polar lessons learned: long-term management based on shared threats in Arctic and Antarctic environments. Front Ecol Environ. 2015;13:316-24.

30. Larsen JA. The boreal ecosystem. Amsterdam: Elsevier; 2013.

31. Buixadé Farré A, Stephenson SR, Chen L, Czub M, Dai Y, Demchev D, Efimov Y, Graczyk P, Grythe H, Keil K. Commercial Arctic shipping through the Northeast Passage: routes, resources, governance, technology, and infrastructure. Polar Geogr. 2014;37:298-324.

32. Haley S, Klick M, Szymoniak N, Crow A. Observing trends and assessing data for Arctic mining. Polar Geogr. 2011;34:37-61.

33. SNL Financial. (2014). SNL metals \& mining. http://www.snl.com/Sectors/ MetalsMining/Default.aspx. Accessed 06 June 2018.

34. Lawrence R, Larsen RK. The politics of planning: assessing the impacts of mining on Sami lands. Third World Q. 2017:1-17.

35. Freeman RE. Strategic management: a stakeholder perspective, vol. 13. Boston: Pitman; 1984

36. Haddaway NR, Kohl C, da Silva NR, Schiemann J, Spök A, Stewart R, Sweet JB, Wilhelm R. A framework for stakeholder engagement during systematic reviews and maps in environmental management. Environ Evid. 2017;6:11.

37. Tengö M, Brondizio E, Malmer P, Elmqvist T, Spierenburg M. A multiple evidence base approach to connecting diverse knowledge systems for ecosystem governance. AMBIO. 2014;10:1007.

38. Collaboration for Environmental Evidence. 2018. Guidelines and Standards for Evidence synthesis in Environmental Management. Version 5.0 (AS Pullin, GK Frampton, B Livoreil \& G Petrokofsky, Eds). http://www.envir onmentalevidence.org/information-for-authors. Accessed 6 June 2018.

39. Haddaway NR, Macura B, Whaley P, Pullin AS. ROSES RepOrting standards for Systematic Evidence Syntheses: pro forma, flow-diagram and descriptive summary of the plan and conduct of environmental systematic reviews and systematic maps. Environ Evid. 2018;7:7.

40. Haddaway NR, Bayliss HR. Shades of grey: two forms of grey literature important for reviews in conservation. Biol Conserv. 2015;191:827-9.

41. Haddaway NR, Collins AM, Coughlin D, Kirk S. The role of Google Scholar in evidence reviews and its applicability to grey literature searching. PLoS ONE. 2015;10:e0138237.

42. Harzing AW. Publish or perish. 2007.

43. Kottek M, Grieser J, Beck C, Rudolf B, Rubel F. World Map of the KöppenGeiger climate classification updated. Meteorologische Zeitschrift 2006;15:259-63. https://doi.org/10.1127/0941-2948/2006/0130.

44. Haddaway NR, Macura B, Whaley P, Pullin AS. ROSES flow diagram for systematic maps. Version 1.0. 2017.

\section{Ready to submit your research? Choose BMC and benefit from:}

- fast, convenient online submission

- thorough peer review by experienced researchers in your field

- rapid publication on acceptance

- support for research data, including large and complex data types

- gold Open Access which fosters wider collaboration and increased citations

- maximum visibility for your research: over 100M website views per year

At BMC, research is always in progress.

Learn more biomedcentral.com/submissions 